\title{
Front Matter: Volume 6964
}

, "Front Matter: Volume 6964," Proc. SPIE 6964, Evolutionary and BioInspired Computation: Theory and Applications II, 696401 (2 May 2008); doi: 10.1117/12.798099

SPIE Event: SPIE Defense and Security Symposium, 2008, Orlando, Florida, SPIE. United States 


\section{PROCEEDINGS OF SPIE}

\section{Evolutionary and Bio-Inspired Computation: Theory and Applications II}

Misty Blowers

Alex F. Sisti

Editors

17-18 March 2008

Orlando, Florida, USA

Sponsored and Published by

SPIE 
The papers included in this volume were part of the technical conference cited on the cover and title page. Papers were selected and subject to review by the editors and conference program committee. Some conference presentations may not be available for publication. The papers published in these proceedings reflect the work and thoughts of the authors and are published herein as submitted. The publisher is not responsible for the validity of the information or for any outcomes resulting from reliance thereon.

Please use the following format to cite material from this book:

Author(s), "Title of Paper," in Evolutionary and Bio-Inspired Computation: Theory and Applications II, edited by Misty Blowers, Alex F. Sisti, Proceedings of SPIE Vol. 6964 (SPIE, Bellingham, WA, 2008) Article CID Number.

ISSN 0277-786X

ISBN 9780819471550

Published by

SPIE

P.O. Box 10, Bellingham, Washington $98227-0010$ USA

Telephone +1 3606763290 (Pacific Time) · Fax +1 3606471445

SPIE.org

Copyright (c) 2008, Society of Photo-Optical Instrumentation Engineers

Copying of material in this book for internal or personal use, or for the internal or personal use of specific clients, beyond the fair use provisions granted by the U.S. Copyright Law is authorized by SPIE subject to payment of copying fees. The Transactional Reporting Service base fee for this volume is $\$ 18.00$ per article (or portion thereof), which should be paid directly to the Copyright Clearance Center (CCC), 222 Rosewood Drive, Danvers, MA 01923. Payment may also be made electronically through CCC Online at copyright.com. Other copying for republication, resale, advertising or promotion, or any form of systematic or multiple reproduction of any material in this book is prohibited except with permission in writing from the publisher. The CCC fee code is 0277-786X/08/\$18.00.

Printed in the United States of America.

Publication of record for individual papers is online in the SPIE Digital Library.

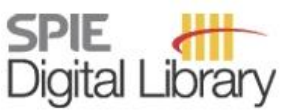

SPIEDigitalLibrary.org

Paper Numbering: Proceedings of SPIE follow an e-First publication model, with papers published first online and then in print and on CD-ROM. Papers are published as they are submitted and meet publication criteria. A unique, consistent, permanent citation identifier (CID) number is assigned to each article at the time of the first publication. Utilization of CIDs allows articles to be fully citable as soon they are published online, and connects the same identifier to all online, print, and electronic versions of the publication. SPIE uses a six-digit CID article numbering system in which:

- The first four digits correspond to the SPIE volume number.

- The last two digits indicate publication order within the volume using a Base 36 numbering system employing both numerals and letters. These two-number sets start with $00,01,02,03,04,05$, $06,07,08,09,0 \mathrm{~A}, 0 \mathrm{~B} \ldots \mathrm{OZ}$, followed by 10-1Z, 20-2Z, etc.

The CID number appears on each page of the manuscript. The complete citation is used on the first page, and an abbreviated version on subsequent pages. Numbers in the index correspond to the last two digits of the six-digit CID number. 


\title{
Contents
}

\author{
$\checkmark$ Conference Committee \\ vii Introduction
}

\section{SESSION 1 COGNITIVE/HUMAN BEHAVIOR MODELING}

696402 The knowledge instinct, cognitive algorithms, modeling of language and cultural evolution (Invited Paper) [6964-01]

L. I. Perlovsky, Harvard Univ. (USA) and Air Force Research Lab. (USA)

696403 Bio-inspiration not bio-imitation [6964-02]

J. Brander, Interactive Engineering (Australia)

696404 Grid-Group Cm-a: performance prediction using environmental and cultural factors [6964-03]

R. Woodley, W. Noll, 21 st Century Systems, Inc. (USA); K. Grantham Lough, D. Krus, Univ. of Missouri-Rolla (USA)

\section{SESSION 2 EVOLVABLE MULTIAGENT SYSTEMS}

696405 A biologically inspired approach to modeling unmanned vehicle teams [6964-04]

R. S. Cortesi, K. S. Galloway, E. W. Justh, Naval Research Lab. (USA)

696406 A bio-inspired swarm robot coordination algorithm for multiple target searching [6964-05] Y. Meng, J. Gan, Stevens Institute of Technology (USA); S. Desai, U.S. Army RDECON-ARDEC (USA)

\section{SESSION 3 PLANNING AND RESOURCE ALLOCATION}

696407 An evolutionary algorithm technique for intelligence, surveillance, and reconnaissance plan optimization [6964-06]

J. T. Langton, Charles River Analytics, Inc. (USA); J. A. Caroli, Air Force Research Lab. (USA);

B. Rosenberg, Charles River Analytics, Inc. (USA)

696408 Using a multi-objective genetic algorithm for developing aerial sensor team search strategies [6964-07]

J. P. Ridder, Innovating Systems, Inc. (USA); J. A. Herweg, Air Force Research Lab. (USA);

J. C. Sciortino, Jr., Naval Research Lab. (USA)

696409 Team-based resource allocation using a decentralized social decision-making paradigm [6964-08]

J. P. Hecker, A. S. Wu, Univ. of Central Florida (USA); J. A. Herweg, Air Force Research Lab.

(USA); J. C. Sciortino, Jr., Naval Research Lab. (USA) 
6964 OA Data modeling enabled dynamical analysis for blogger state-of-mind modeling and prediction [6964-09]

H. M. Jaenisch, Alabama A\&M Univ. (USA) and Licht Strahl Engineering Inc. (USA); M. J. Coombs, Diplomacy Media Research (USA); J. W. Handley, Licht Strahl Engineering Inc. (USA) and Amtec Corp. (USA); N. G. Albritton, Amtec Corp. (USA); M. E. Edwards, Alabama A\&M Univ. (USA)

6964 OB Developing an intelligence analysis process through social network analysis [6964-10] T. Waskiewicz, P. LaMonica, Air Force Research Lab. (USA)

6964 OC A qualia representation of cyberspace [6964-11] T. H. Lacey, R. F. Mills, R. A. Raines, M. E. Oxley, K. W. Baver, Air Force Institute of Technology (USA); S. K. Rogers, Air Force Research Lab. (USA)

6964 OF Secure wireless knowledge management for intelligence analysis [6964-19] C. H. Clark, Vision Systems \& Technology, Inc. (USA); J. Spina, M. Corey, Air Force Research Lab. (USA)

\section{SESSION 5 SYSTEM/COMPONENT DESIGN AND OPTIMIZATION}

6964 OG IR wireless cluster synapses of HYDRA very large neural networks [6964-17]

T. Jannson, T. Forrester, Physical Optics Corp. (USA)

$6964 \mathrm{OH}$ Fitness landscape analysis of evolved image transforms for defense applications [6964-14] M. R. Peterson, Wright State Univ. (USA); G. B. Lamont, Air Force Institute of Technology (USA)

69640 A genetic algorithm approach to optimal spatial sampling of hyperspectral data for target tracking [6964-15]

B. R. Secrest, Air Force Institute of Technology (USA); J. R. Vasquez, Numerica Corp. (USA)

6964 0J Efficient global optimization of a limited parameter antenna design [6964-16] T. H. O'Donnell, Air Force Research Lab. (USA) and ARCON Corp. (USA); H. L. Southall, Air Force Research Lab. (USA) and Vistronix, Inc. (USA); B. Kaanta, Air Force Research Lab. (USA)

Author Index 


\title{
Conference Committee
}

\author{
Symposium Chair
}

Larry B. Stotts, Defense Advanced Research Projects Agency (USA)

Symposium Cochair

Ray O. Johnson, Lockheed Martin Corporation (USA)

Track Chair

Dawn A. Trevisani, Air Force Research Laboratory (USA)

Conference Chairs

Misty Blowers, Air Force Research Laboratory (USA)

Alex F. Sisti, Air Force Research Laboratory (USA)

Program Committee

Robert W. Bird, Red Lambda, Inc. (USA)

Peter M. LaMonica, Air Force Research Laboratory (USA)

Sushil J. Lewis, University of Nevada, Reno (USA)

Teresa H. O'Donnell, Air Force Research Laboratory (USA)

John C. Sciortino, Jr., Naval Research Laboratory (USA)

Sharon M. Walter, Air Force Research Laboratory (USA)

Session Chairs

1 Cognitive/Human Behavior Modeling

Emily Budlong, Air Force Research Laboratory (USA)

2 Evolvable Multiagent Systems

Barry R. Secrest, Air Force Institute of Technology (USA)

3 Planning and Resource Allocation

John C. Sciortino, Jr., Naval Research Laboratory (USA)

$4 \quad$ Knowledge Discovery and Exploitation

Peter M. LaMonica, Air Force Research Laboratory (USA)

5 System/Component Design and Optimization

Teresa H. O'Donnell, Air Force Research Laboratory (USA) 
Downloaded From: https://www.spiedigitallibrary.org/conference-proceedings-of-spie on 26 Apr 2023

Terms of Use: https://www.spiedigitallibrary.org/terms-of-use 


\section{Introduction}

The conference on Evolutionary and Bio-Inspired Computation: Theory and Applications was back by popular demand, settling into its second year at the Defense, Security and Sensing 2008 symposium. Several interesting presentations were made by some of the brightest luminaries in the computational intelligence and defense communities, covering such topics as:

- data modeling enabled dynamical analysis for blogger state-of-mind modeling and prediction

- developing an intelligence analysis process through social network analysis

- bio-inspired computational techniques for fusion of data from multiple sources

- secure wireless knowledge management for intelligence analysis

- cognitive algorithms for engineering

- modeling of language and cultural evolution

- bio-inspiration in computers

- performance prediction using environmental and cultural factors

In addition, this year's conference included a spirited panel discussion titled "BioInspired Computing for Homeland Security: Issues and Answers," and an engaging keynote presentation by Dr. Leonid Perlovsky, titled "The Knowledge Instinct: cognitive algorithms for engineering, and modeling of language and cultural evolution."

As always, any conference is only as good as the efforts of its planners, authors, presenters, and attendees. In that respect, we have yet to see a better mix of all the ingredients. For those of you who attended, we hope you came away a little more enlightened than when you arrived. We sincerely hope you appreciate the papers that follow, and that they serve to foster further research into, and application of, evolutionary and bio-inspired computation. We look forward to seeing you next year at Evolutionary and Bio-Inspired Computation: Theory and Applications III, to be held at the SPIE Defense, Security and Sensing Symposium, 1317 April 2009, in the Orlando World Center Marriott Resort \& Convention Center, Orlando (Kissimmee), Florida. 
Downloaded From: https://www.spiedigitallibrary.org/conference-proceedings-of-spie on 26 Apr 2023

Terms of Use: https://www.spiedigitallibrary.org/terms-of-use 